\title{
Comments
}

\section{No Evidence for Oncogenic Mutations in Guanine Nucleotide-Binding Proteins of Human Adrenocortical Neoplasms}

\author{
MARTIN REINCKE*, MICHAEL KARL, \\ WILLIAM TRAVIS, AND GEORGE P. CHROUSOS \\ Developmental Endocrinology Branch, National Institute of Child Health and Human Development, and the \\ Clinical Pathology Branch, National Cancer Institute, National Institutes of Health, \\ Bethesda, Maryland 20892
}

\begin{abstract}
G-Proteins are membrane-bound heterotrimeric polypeptides that couple receptor signals to second messenger systems such as cAMP. Recently, point mutations at 2 codons of the highly preserved $\alpha$-chain of $G_{8}$, the adenyl cyclase-stimulating $G$-protein, were found in $G H$ secreting pituitary tumors. These mutations resulted in constitutively activated $\mathrm{G}_{\mathrm{B}} \alpha$ and high intracellular cAMP levels. In addition, point mutations at similar codons of a different $\mathrm{G}$-protein, $\mathrm{G}_{\mathrm{i}} \alpha 2$, were reported in adrenocortical neoplasms, suggesting a potential role of this isoform in the genesis of these tumors. We reevaluated the frequency of constitutively activating point mutations in the $\alpha$-chain of the stimulatory $\left(\mathrm{G}_{\mathrm{s}} \alpha\right)$ and inhibitory $\left(\mathrm{G}_{\mathrm{i}} \alpha 2\right) \mathrm{G}$-proteins in human adrenocortical tumors. Seven adrenocortical carcinomas, 2 human adrenocortical tumor cell lines, and 11 adrenocortical adenomas were studied.
\end{abstract}

Genomic DNA was purified from either frozen tumor tissue or paraffinembedded sections. Using specific primers and the polymerase chain reaction, DNA fragments surrounding codons 201 and $227\left(\mathrm{G}_{\mathrm{s}} \alpha\right)$ and 179 and $205\left(\mathrm{G}_{\mathrm{i}} \alpha 2\right)$ were amplified and visualized on a $2 \%$ agarose gel. In a second asymmetric polymerase chain reaction, using nested primers, single stranded DNA was generated using $1-10 \mu \mathrm{L}$ of the initial amplification mixture and directly sequenced using the dideoxy chain termination method of Sanger. We found no mutations at codons 201,227 and 179,205 of $\mathrm{G}_{\mathrm{s}} \alpha$ and $\mathrm{G}_{\mathrm{i}} \alpha 2$, respectively, in the tumors studied. We conclude that previously identified oncogenic point mutations in the stimulatory and inhibitory $\alpha$-chain of G-proteins do not appear to be present at high frequency in adrenal neoplasms. Thus, the mechanism(s) of tumorigenesis in these tumors is different from that in $\mathrm{GH}$-secreting adenomas and may involve oncogenic mutations of other cell constituents. ( $J$ Clin Endocrinol Metab 77: 1419-1422, 1993)
$\mathrm{T}_{\mathrm{s}, \mathrm{we}}$ WO DECADES ago, adrenocortical neoplasms were considered rare. However, with wider application of ultrasound, computed tomography, and, more recently, magnetic resonance imaging, it became evident that the prevalence of clinically silent, incidentally detected adrenal neoplasms is much higher than previously assumed (1). However, the tumorigenesis of adrenocortical neoplasms is not well understood, and the molecular mechanisms that lead to adrenal tumor formation have not been extensively studied.

G-Proteins involved in signal transduction are heterotrimers consisting of $\alpha-, \beta$-, and $\gamma$-subunits that bind guanine nucleotide and interact with specific receptors and effectors (2). G-Protein activation normally requires the interaction of the inactive GDP-bound heterotrimer with a ligand-occupied receptor, resulting in the exchange of GTP for GDP and dissociation of the $\alpha$-unit (3). Recently, mutations in the $\alpha$ unit of $G_{5}$, the adenylyl cyclase-stimulating protein, have been described in GH-secreting pituitary adenomas (4). These mutations caused an amino acid exchange at the highly conserved codons $\operatorname{Arg}^{201}$ and $\mathrm{GIn}^{227}$, resulting in a constitu-

Received January 20, 1993. Accepted May 25, 1993.

Address all correspondence and requests for reprints to: George $P$ Chrousos, M.D., National Institutes of Health, Building 10, Room 10N262, 9000 Rockville Pike, Bethesda, Maryland 20892.

* Recipient of a fellowship from the Deutsche Forschungs-gemeinschaft $(\operatorname{Re} 7522-1)$. tive activation of $G_{5} \alpha$ by inhibition of endogenous GTPase activity. These putative oncogenic mutations, which were called Gsp, were found in approximately $40 \%$ of $\mathrm{GH}$-producing tumors and $4 \%$ of thyroid tumors $(5,6)$. Point mutations at similar codons of a different G-protein, codons 179 and 205 of $G_{\mathrm{i}} \alpha 2$, were reported in adrenocortical neoplasms, suggesting a potential role of mutated $\mathrm{G}_{\mathrm{i}} \alpha 2$ (Gip 2) in the tumorigenesis of adrenocortical masses (5). However, the initially described series was rather small $(n=11)$, demonstrating mutations in three $(27 \%)$ tumors. We, therefore, reevaluated the frequency of Gsp and Gip 2 in a larger series of adrenocortical tumors.

\section{Subjects and Methods}

\section{Isolation of DNA from tissue specimens}

Adrenocortical tumor tissue was obtained at adrenalectomy from 18 patients. DNA was isolated from 7 adrenocortical carcinomas and 11 adrenocortical adenomas (for clinical data, see Table 1). In 10 cases, tumor DNA was extracted from paraffin-embedded sections accumulated over a 30 -yr period. In 8 cases, frozen $(-80 \mathrm{C})$ tumor tissue and corresponding normal leukocytic DNA were studied. In addition, DNA from the 2 currently available human adrenocortical tumor cell lines were studied. SW13, a nonsecretory human adrenocortical tumor cell line maintained in Ham's F-10 medium with $10 \%$ fetal bovine serum, was received from the American Type Culture Collection (Rockville, $\mathrm{MD}$ ). $\mathrm{NCl} \mathrm{H-295,} \mathrm{a} \mathrm{human} \mathrm{steroid-producing} \mathrm{adrenocortical} \mathrm{tumor}$ 
TABLE 1. Clinical data of the patients whose tumors were studied

\begin{tabular}{|c|c|c|c|c|c|c|}
\hline $\begin{array}{c}\text { Patient } \\
\text { no. }\end{array}$ & Sex & $\begin{array}{l}\text { Age } \\
\text { (yr) }\end{array}$ & $\begin{array}{l}\text { Tumor size } \\
\text { (cm) }\end{array}$ & Histology & Clinical presentation & DNA source \\
\hline 1 & $\mathbf{F}$ & 15 & $25 \times 17 \times 8$ & Liver met., adren. carc. & Virilization & Frozen tissue \\
\hline 2 & $\mathbf{F}$ & 50 & $9 \times 8 \times 7$ & Adren, carc. & Conn's syndrome & Frozen tissue \\
\hline 3 & $\mathrm{M}$ & 25 & $9 \times 8 \times 5$ & Adren. carc. & Cushing's syndrome, MEN I & Paraffin \\
\hline 4 & $\mathbf{F}$ & 14 & $7 \times 4 \times 2$ & Liver met., adren. carc. & Non-secretory tumor & Paraffin \\
\hline 5 & $\mathbf{F}$ & 29 & $8 \times 6 \times 1$ & Brain met, adren. carc. & Non-secretory tumor & Paraffin \\
\hline 6 & $\mathbf{F}$ & 22 & $12 \times 6 \times 10$ & Adren. carc. & Cushing's syndrome & Paraffin \\
\hline 7 & $\mathbf{F}$ & 27 & $17 \mathrm{~cm}$ diam. & Adren. carc. & Virilization & Paraffin \\
\hline 8 & $\mathbf{F}$ & 67 & $2.5 \mathrm{~cm}$ diam. & Adrenal adenoma & Cushing's syndrome & Frozen tissue \\
\hline 9 & $\mathbf{F}$ & 65 & $4 \times 5 \times 3$ & Adrenal adenoma & Cushing's syndrome & Frozen tissue \\
\hline 10 & $\mathbf{F}$ & 41 & $3 \mathrm{~cm}$ diam. & Adrenal adenoma & Conn's syndrome & Frozen tissue \\
\hline 11 & $\mathbf{F}$ & 49 & $3 \mathrm{~cm}$ diam. & Adrenal adenoma & Cushing's syndrome & Frozen tissue \\
\hline 12 & $\mathrm{~F}$ & 50 & $1 \mathrm{~cm}$ diam. & Adrenal adenoma & Conn's syndrome & Frozen tissue \\
\hline 13 & $\mathrm{~F}$ & 39 & $4 \times 4 \times 3$ & Adrenal adenoma & Cushing's syndrome & Frozen tissue \\
\hline 14 & $\mathrm{~F}$ & 51 & $1.5 \mathrm{~cm}$ diam. & Adrenal adenoma & Conn's syndrome & Paraffin \\
\hline 15 & $\mathrm{~F}$ & 39 & $2 \times 2 \times 1$ & Adrenal adenoma & Conn's syndrome & Paraffin \\
\hline 16 & $\mathrm{~F}$ & 48 & $3 \times 3 \times 2$ & Adrenal adenoma & Conn's syndrome & Paraffin \\
\hline 17 & $\mathbf{F}$ & 30 & $4 \times 2 \times 2$ & Adrenal adenoma & Conn's syndrome & Paraffin \\
\hline 18 & $\mathrm{~F}$ & 48 & $1 \times 3$ & Adrenal adenoma & Conn's syndrome & Paraffin \\
\hline
\end{tabular}

Adr. canc., Adrenocortical carcinoma; met., metastsis; diam., diameter; MEN I, multiple endocrine neoplasia type 1.

cell line maintained in HITES (containing hydrocortisone, insulin, ethanolamine and selenite) medium with $2 \%$ fetal bovine, was kindly provided by Dr. E. Gazdar (7).

\section{DNA preparation}

DNA was isolated from paraffin-embedded specimens (8), leukocytes, or frozen tumor sections obtained at surgery (9), as previously described. Tissue samples were derived from a central portion of the tumor to minimize the possibility of contamination with normal tissue. Representative sections of the tumor material were examined by light microscopy and shown to consist of more than $90 \%$ tumor cells. For paraffinembedded specimens, $10-\mu \mathrm{m}$ sections were carefully cut and placed in sterile Eppendorf tubes using new gloves, forceps, and a cleaned microtome blade for every tumor block.

\section{Polymerase chain reaction (PCR) amplification of genomic $D N A$}

PCR was used to amplify DNA fragments surrounding codons 201 and 227 of $\mathrm{G}_{s} \alpha$ and codons 179 and 205 of $\mathrm{G}_{i} \alpha 2$, respectively (10). One and $10 \mu \mathrm{L}$ DNA preparation from paraffin-embedded tissues or $1 \mu \mathrm{g}$ DNA from frozen tissue or leukocytic DNA were amplified in a $100-\mu \mathrm{L}$ PCR mixture containing deoxynucleotide triphosphates $(200 \mu \mathrm{mol} / \mathrm{L}$ each), up and down-stream oligonucleotide primers $(0.3 \mu \mathrm{mol} / \mathrm{L}$ each $)$, $0.01 \%$ gelatin, $50 \mathrm{mmol} / \mathrm{L} \mathrm{KCl}, 10 \mathrm{mmol} / \mathrm{L}$ Tris- $\mathrm{HCl}(\mathrm{pH} 8.3), 1.5 \mathrm{mmol} /$ $\mathrm{L} \mathrm{MgCl}_{2,}$ and $2.5 \mathrm{U}$ Taq polymerase (Perkin-Elmer Cetus, Norwalk, CT). The following primers were used: codon 201 of $G_{5} \alpha, 5^{\prime}$-GTG ATC AAG CAG GCT GAC TAT GTG-3' and 5'-GGT GAA TGT CAA GAA ACC ATG-3' [299-basepair (bp) fragment]; codon 227 of $\mathrm{G}_{5} \alpha, 5^{\prime}$-GTC AAC TTC CAG TAA GCC AAC-3' and 5'-CTG GTT GTC CTC CCG GAT GAC- $3^{\prime}$ (350 bp); codon 179 of $\mathrm{G}_{i} \alpha 2,5^{\prime}$-CCC CCC ATC CCC AGC TAC CT- $3^{\prime}$ and $5^{\prime}$-CCG ACC TGT CCA CAT GCT CGC-3' (168 bp); and codon 205 of $\mathrm{G}_{\mathrm{j}} \alpha 2,5^{\prime}$-GAG AAA TGG GGT AGA AAG CCT-3' and 5'-TCT CAC CAT CTC CTC GTC CTC-3' (195 bp). Special precautions were taken to avoid contamination of the PCR samples. In all PCR experiments, samples containing no DNA were included as negative controls. The amplification protocol consisted of denaturation at $95 \mathrm{C}$ for $5 \mathrm{~min}$, followed by 30-40 cycles consisting of annealing at $55 \mathrm{C}$ for $1.5 \mathrm{~min}$, primer extension at $72 \mathrm{C}$ for $1.5 \mathrm{~min}$, and denaturation at $94 \mathrm{C}$ for $1 \mathrm{~min}$. All amplified samples were examined by agarose gel electrophoresis to confirm successful amplification of each of the regions of the $\mathrm{G}_{\mathrm{s}} \alpha$ and $\mathrm{G}_{\mathrm{i}} \alpha 2$ genes.

\section{Direct sequencing of the PCR product}

In a second, asymmetric PCR, using one of the nested primers in a 100 -fold excess, single stranded DNA was generated, purified on Ultrapure MC filters (Millipore, Bedford, MA), and lyophilized at room temperature. Using the dideoxy chain termination method of Sanger et al. (11), the PCR product was sequenced (T7-DNA polymerase, Sequenase 2.0 , U.S. Biochemical Corp., Cleveland, OH) with $\left[\alpha-{ }^{35} \mathrm{~S}\right]$ deoxy-ATP and run on a $6 \%$ denaturing polyacrylamide gel. Autoradiography was performed with Kodak XAR 2 films (Eastman Kodak, Rochester, NY).

\section{Results}

In all but two cases, DNA fragments surrounding codons 201 and 227 of $G_{5} \alpha$ and codons 179 and 205 of $G_{i} \alpha 2$ were successfully amplified by PCR and showed the predicted size on agarose gel electrophoresis. In two 31- and 32-yr-old paraffin-embedded tumor specimens, the 299 - and 350-bp long fragments surrounding codons 201 and 227 could not be amplified, probably due to DNA degradation, whereas the shorter fragments surrounding codons 179 (168 bp) and 205 (195 bp) could be efficiently amplified in these cases.

Direct sequencing of the PCR product from normal leukocyte DNA revealed the wild-type sequence for the amplified regions. All adrenal adenomas, all adrenocortical carcinomas, and the two adrenocortical tumor cell lines showed only the wild-type sequence at codons 201 and 227 of $G_{5} \alpha$ and codons 179 and 205 of $\mathrm{G}_{i} \alpha 2$ (Table 2 and Fig. 1). In addition, no mutations were found at other codons of $\mathrm{G}_{\mathrm{s}} \alpha$ and $G_{i} \alpha 2$ in these amplifications.

\section{Discussion}

Constitutively activating mutations in G-proteins were found in several endocrine neoplasms. Adenylcyclase activity was extremely elevated under basal conditions in these tumors (12). Clinically, the GH-secreting adenomas were smaller in diameter, less responsive to GH-releasing-hormone, and more sensitive to somatostatin- and dopamineinduced $\mathrm{GH}$ inhibition than adenomas with no mutated $\mathrm{G}_{\mathrm{s}}$ 
TABLE 2. Prevalence of oncogenic point mutations in the $\alpha$-chain of $\mathrm{G}_{\mathrm{s}}$ and $\mathrm{G}_{\mathrm{i} 2}$ in adrenocortical tumors: comparison with the results of Lyons et al. (5)

\begin{tabular}{lrccc}
\hline & $\mathrm{n} \begin{array}{c}\mathrm{G}_{\mathrm{s}} \alpha \text { codon } \\
201 / \text { codon } \\
227(\%)\end{array}$ & $\begin{array}{c}\mathrm{G}_{\mathrm{i}} \alpha 2 \text { codon } 179 / \text { codon } \\
205(\%)\end{array}$ \\
\hline $\begin{array}{l}\text { Adrenal carcinomas } \\
\quad \text { Reincke } \text { et al. }\end{array}$ & 7 & 0 & 0 & 0 \\
$\quad \begin{array}{l}\text { Lyons et al. } \\
\text { Adrenocortical tumor cell lines } \\
\quad \text { Reincke } \text { et al. }\end{array}$ & 6 & 0 & 16.6 & 0 \\
$\begin{array}{l}\text { Adrenal adenomas } \\
\quad \text { Reincke } \text { et al. }\end{array}$ & 2 & 0 & 0 & 0 \\
$\quad$ Lyons et al. & 11 & 0 & 0 & 0 \\
\hline & 5 & 0 & 40 & 0 \\
\hline
\end{tabular}

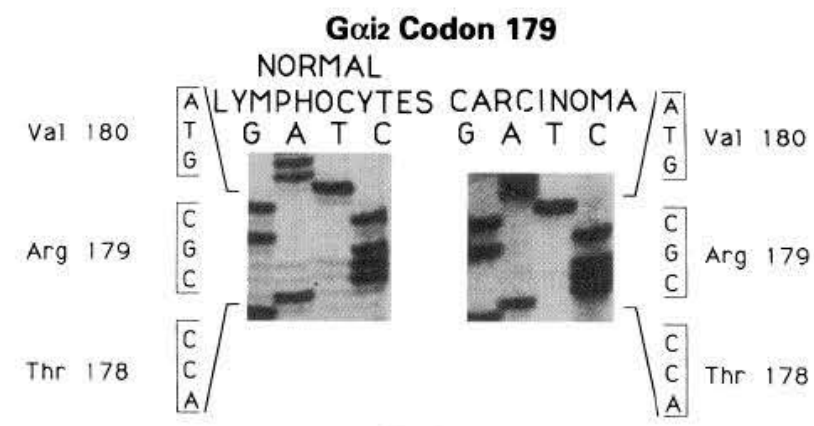

Goi2 Codon 205
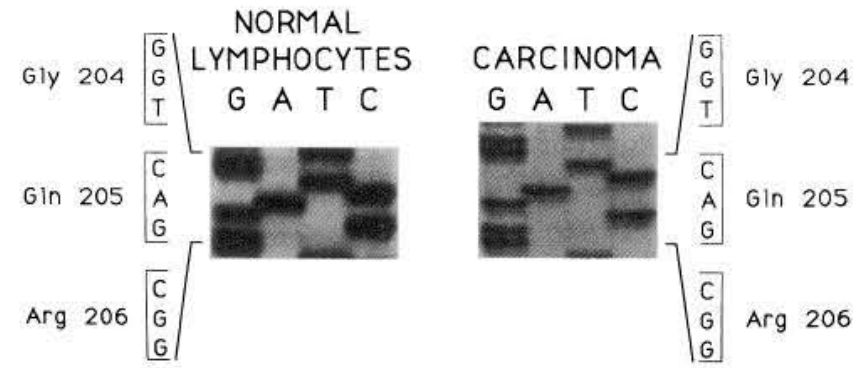

FIG. 1. Sequencing analysis of the amplified genomic fragments of $\mathrm{G}_{3} \alpha 2$ surrounding codons 179 and 205 showing only the wild-type sequence in normal lymphocytic DNA (left) and DNA from an adrenocortical carcinoma (right). Top, Codon 179; bottom, codon 205.

(12-14). Somatic mutations in $\mathrm{G}_{5} \alpha$ were also found in benign and malignant thyroid neoplasms. Lyons et al. (5) reported a low incidence of Gsp mutations in thyroid neoplasms (1 of 25 cases), whereas Suarez et al. (6) found constitutively activating mutations of $\mathrm{G}_{\mathrm{s}} \alpha$ in $10 \%$ of thyroid tumors. Goretzki et al. (15) reported Gsp mutations in all 25 multinodular goiters studied from an iodine-deficient area, but in none of 3 thyroid adenomas. The Gsp mutations were multifocally distributed throughout the tissue. These researchers, therefore, concluded that the Gsp oncogene constituted one of the genetic bases of this disease. Whereas Gsp is important in endocrine tumors, it does not play a role in the pathogenesis of other neoplasms. No Gsp mutations were found in 218 nonendocrine tumors studied, including breast, colon, and gastric carcinomas (5).

Somatic mutations in a different G-protein, $\mathrm{G}_{\mathrm{i}} \alpha 2$, corresponding to codons 201 and 227 of $\mathrm{G}_{\mathrm{s}} \alpha$, were identified by Lyons et al. (5) in 3 of 11 (27\%) adrenocortical neoplasms using PCR and oligonucleotide-specific hybridization. Although the functional significance of these putative oncogenic mutations Gip 2 was not proven, several indirect lines of evidence suggested promotion of cell proliferation by constitutively activated $\mathrm{G}_{i} \alpha 2$. However, using PCR and direct sequencing, we were unable to confirm the results of Lyons et al. None of 7 adrenal carcinomas and 11 adenomas showed mutations at codons 179 and 205 of $\mathrm{G}_{\mathrm{i}} \alpha 2$. In addition, although oncogenic mutations are generally more frequent in human tumor cell lines than in tumor tissue, the 2 currently available human adrenocortical tumor cell lines had wildtype sequences at codons 179 and 205 of $\mathrm{G}_{\mathrm{i}} \alpha 2$. The differences between our results and the data of Lyons et al. cannot be explained by the different methodologies used in these studies. Direct sequencing of PCR-amplified DNA fragments is equally sensitive in detecting point mutations in the tumor genome compared to allele-specific oligonucleotide hybridization, which was used by Lyons et al. More likely, our data suggest that the putative oncogene Gip 2 does not play a major role in the tumorigenesis of human adrenocortical neoplasias.

Several recent publications suggested that oncogenes other than Gip 2 are involved in adrenocortical tumor formation. Yano et al. (16) consistently showed loss of constitutional heterozygosity for alleles at chromosomes $11 \mathrm{q}, 13 \mathrm{q}$, and $17 p$ in adrenocortical carcinomas, but not in adrenal adenomas or hyperplastic adrenal lesions. Chromosome $11 \mathrm{q}$ seems to be important in adrenal tumorigenesis. $11 \mathrm{q} 13$ is the locus of the multiple endocrine neoplasia-1 tumor suppressor gene (17), and adrenal tumor formation is part of this entity. However, the deletion of the chromosomal region $11 \mathrm{q} 13$ present in parathyroid and pancreatic tumors (17) is not always present in adrenal tumors of these patients (18). The Wiedemann-Beckwith syndrome, which is associated with allelic loss of $11 \mathrm{q} 15$, is characterized by early development of Wilm's tumors and adrenocortical carcinomas (19). Chromosome 13 is the locus of the retinoblastoma gene (20); however, no studies have been reported elucidating the pathophysiological significance of retinoblastoma gene mutations in adrenal neoplasms. The short arm of chromosome 17 contains the p53 gene, which is most frequently known to be mutated in human cancer (21). A germ-line mutation in the p53 gene is associated with the Li-Fraumeni syndrome in cancer-prone families (22) whose members may develop adrenocortical carcinoma (23). In summary, these data together with our results show that molecular mechanisms different from the previously suggested oncogenes Gsp and Gip 2 are involved in the tumorigenesis of adrenocortical neoplasms.

\section{References}

1. Copeland PM. 1983 The incidentally discovered adrenal mass. Ann Intern Med. 98:940-945.

2. Simon MI, Strathmann MP, Gautum N. 1991 Diversity of G proteins in signal transduction. Science. 252:802-808.

3. Bourne HR, Sanders DA, McCormick F. 1990 The GTPase superfamily: a conserved switch for diverse cell functions. Nature. 348:152-132.

4. Landis CA, Masters SB, Spada A, Pace AM, Bourne HR, Vallar 
L. 1989 GTPase inhibiting mutations activate the $\alpha$ chain of Gs and stimulate adenylyl cyclase in human pituitary tumours. Nature. 340:692-696.

5. Lyons J, Landis CA, Harsh G, et al. 1990 Two $G$ protein oncogenes in human endocrine tumors. Science. 249:655-659.

6. Suarez HG, du Villard JA, Caillou B, Schlumberger M, Parmentier C, Monier R. 1991 Gsp mutations in human thyroid tumors. Oncogene. 6:677-679.

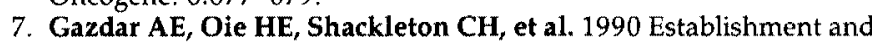
characterization of a human adrenocortical carcinoma cell line that express multiple pathways of steroid biosynthesis. Cancer Res. 50:5488-5496.

8. Wright DK, Manos MM. 1990 Sample preparation from paraffinembedded tissues. In: Innis MA, Gelfand DH, Sninsky JJ, White IJ, eds. PCR protocols: a guide to methods and applications. San Diego: Academic Press; 153-158.

9. Sambrook J, Fritsch EF, Maniatis T. 1989 Molecular cloning-a laboratory manual, 2nd ed. Cold Spring Harbor: Cold Spring Harbor Laboratory; pp 9.16-9.23.

10. Saiki RK, Gelfand DH, Stoffel S, et al. 1988 Primer-directed enzymatic amplification of DNA with a thermostable DNA polymerase. Science. 239:487-491.

11. Sanger F, Nicklen S, Coulson AR. 1977 DNA sequencing with chain terminating inhibitors. Proc Natl Acad Sci USA. 74:54635467.

12. Vallar L, Spada A, Giannattasio G. 1987 Altered Gs and adenylate cyclase activity in hunan $\mathrm{GH}$-secreting pituitary adenomas. Nature. 330:566-568,

13. Landis CA, Harsh $\mathrm{G}$, Lyons J, Davis RL, McCormick F, Bourne HR. 1990 Clinical characteristics of acromegalic patients whose pituitary tumors contain mutant Gs protein. I Clin Endocrinol Metab. 71:1416-1420.

14. Spada A, Arosio M, Bochicchio D, et al. 1990 Clinical, biochemical, and morphological correlates in patients bearing growth hormonesecreting pituitary tumors with or without constitutively active adenylyl cyclase. J Clin Endocrinol Metab. 71:1421-1426.

15. Goretzki PE, Lyons J, Roeher HD, Bourne HR. 1991 Mutational activated GS protein (Gsp)-determination for multinodular goiter? Acta Endocrinol (Copenh). 124(Suppl 1):15.

16. Yano T, Linehan M, Anglard P, et al. 1989 Genetic changes in human adrenocortical carcinoma. J Natl Cancer Inst. 81:518-523.

17. Larson C, Skogseid B, Öberg K, Nakamura $Y$, Nordenskjöd M. 1986 Multiple endocrine neoplasia type 1 gene maps to chromosome 11 and is lost in insulinoma. Nature. 332:85-87.

18. Skogseid B, Larsson C, Lindgren PG, et al. 1992 Clinical and genetic features of adrenocortical lesions in multiple endocrine neoplasia type I. J Clin Endocrinol Metab. 75:76-81.

19. Koufos A, Grundy P, Morgan K, et al. 1989 Familial WiedemannBeckwith syndrome and a second Wilms tumor locus both map to 11p15.5. Am J Genet. 44:711-719.

20. Friend SH, Bernards R, Rogelj S, et al. 1986 A human DNA sequence with properties of the gene that predispose to retinoblastoma and osteosarcoma. Nature. 323:643-646.

21. Hollstein M, Sidransky D, Vogelstein B, Harris CC. 1991 P53 mutations in human cancer. Science. 253:49-53.

22. Srivastava S, Zou Z, Pirollo K, Blattner W, Chang EH. Nature; 1990 Germ-line transmission of a mutated p53 gene in a cancerprone family with Li-Fraumeni syndrome. 348:747-749.

23. Li FP, Fraumeni Jr JF. 1969 Soft-tissue sarcomas breast cancer and other neoplasms: a familial syndrome? Ann Intern Med. 71:747752. 